\title{
Input of litter in deforested and forested areas of a tropical headstream
}

\author{
Carvalho, EM. ${ }^{\text {a* }}$ and Uieda, VS. ${ }^{\text {b* }}$ \\ ${ }^{a}$ Centro Universitário da Grande Dourados - UNIGRAN, \\ Rua Balbina de Mattos, 2121, Jardim Universitário, Dourados, MS, Brazil

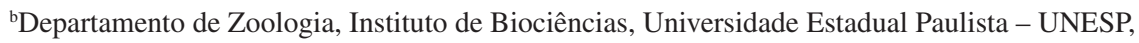 \\ CP 510, CEP 18618-000, Botucatu, SP, Brazil \\ *e-mail: carvalho.em@gmail.com; vsuieda@ibb.unesp.br
}

Received November 3, 2008 - Accepted December 23, 2008 - Distributed May 31, 2010

(With 6 figures)

\begin{abstract}
Riparian vegetation is the main source of leaves and the main energy source for low order streams. Therefore, changes in its composition affect the structure and processes in streams. We studied the contribution of the riparian vegetation by analysing the annual input of litter in deforested and forested areas of a tropical stream. The lateral, vertical (aerial) and horizontal (drift) litter inputs were analysed separately. The lateral input differed significantly between the two areas and included mostly fallen dry leaves. The vertical input, represented mainly by fallen dry leaves, occurred only in the forested area. The drift transport of litter was not significantly different between the deforested and forested areas and the input was composed mostly by CPOM. The removal of the native forest was clearly reflected in the low contribution of leaf litter in the deforested area.
\end{abstract}

Keywords: annual input, Brazilian stream, detritus, riparian vegetation.

\section{Aporte de folhiço em áreas sem mata e com mata de galeria de um riacho tropical}

\section{Resumo}

A vegetação ripária constitui um importante recurso energético em riachos de pequena ordem. Assim, mudanças em sua composição afetam a estrutura e os processos ecológicos em riachos. A contribuição da vegetação ripária foi analisada pela entrada anual de folhiço em duas áreas de um riacho tropical, uma cercada por mata de galeria e outra somente com vegetação arbustiva. A entrada lateral, vertical (aérea) e horizontal (drift) de material vegetal foi avaliada separadamente. A entrada lateral, composta principalmente de folhas secas, apresentou diferença significativa entre as duas áreas. A entrada vertical, também representada principalmente por folhas secas, ocorreu somente na área com mata de galeria. O transporte por drift não foi significativamente diferente entre as áreas, e a entrada foi composta principalmente de matéria orgânica particulada grossa. $\mathrm{O}$ efeito negativo da remoção da mata nativa foi bastante evidente pela baixa contribuição de folhas na área sem mata.

Palavras-chave: aporte anual, detritos, riacho brasileiro, vegetação ripária.

\section{Introduction}

Every year streams receive a large amount of litter dry mass per square metre (Elosegi and Pozo, 2005). A large part of these detritus input consists of leaves from riparian vegetation (Abelho, 2001; Elosegi and Pozo, 2005). Headwater streams are particularly influenced by riparian vegetation which reduces autotrophic production by shading and supplies energy in the form of vegetal matter of allochthonous origin (Vannote et al., 1980; Abelho, 2001; Graça, 2001; Graça and Canhoto, 2006; Uieda and Motta, 2007).
A qualitative and quantitative change in the riparian forest affects the litter input to streams and thus can modify the structure of the whole biotic community (Afonso et al., 2000; Graça, 2001). In Brazil, as well as in many other countries, the degradation of riparian vegetation results from the disordered expansion of agricultural borders (Rodrigues and Gandolfi, 2001; Heartsill-Scalley and Aide, 2003), contributing to the formation of immense open areas, characterised by grassy and herbaceous vegetation. 
The type of vegetation cover and rainfall can also determine conditions of autotrophy or heterotrophy in streams, having a strong effect upon the stream food web structure and dynamics, as shown by Uieda and Motta (2007) for some tropical streams.

Those changes in land cover can also modify the physical conditions of streams (Heartsill-Scalley and Aide, 2003), with a forest landscape certainly contributing with more biomass to the stream than herbaceous vegetation (Afonso et al., 2000; Heartsill-Scalley and Aide, 2003). However, it is important to determine the actual contribution of the litter input for different conditions of riparian vegetation (Elosegi and Pozo, 2005).

Leaf litter enters streams mainly in a large burst during the period of leaf abscission, and can be either trapped in the reach, or transported downstream (Elosegi, 2005). The entrance ways of this allochthonous matter in the stream include transport by drift from upstream, by direct or vertical input, and by lateral input of material deposited on the forest floor and mobilised by wind or other agents (Elosegi and Pozo, 2005). Thus, the regional climate, the characteristics of the stream and of the semi-deciduous forest could be the main factors that determine this seasonal leaf-litter pattern (Abelho, 2001).

The aim of the present study was to assess and compare the annual input and transport of litter in two different areas of a tropical stream: one area shaded by the presence of a dense gallery forest and the other, located downstream from the first, deforested and with scattered herbaceous vegetation. This analysis is important, as emphasised before by Rezende and Mazzoni (2005), in order to verify potential differences in the relative importance of allochthonous input on a spatial and temporal scale, which can have a strong influence upon the maintenance of aquatic fauna.

\section{Material and Methods}

The study was carried out at Ribeirão da Quinta stream (23 $06^{\prime} 47^{\prime \prime} \mathrm{S}$ and $\left.48^{\circ} 29^{\prime} 46^{\prime \prime} \mathrm{W}\right)$, a third order stream located in southeastern Brazil, on a cattle raising farm, at an elevation of $743 \mathrm{~m}$ a.s.l. and distant from urban areas.

Two areas of this stream of approximately $120 \mathrm{~m}^{2}$ were chosen for the study. The first area, called "Forested area", is shaded by a well-preserved gallery forest. The riparian trees include Nectandra sp. (Lauraceae), Cabralea canjerana (Vell.) Mart. (Meliaceae), Acacia sp., Inga sp. and Piptadenia gonoacantha (Mart.) J.F. Macbr. (Mimosaceae), Mollinedia sp. (Monimiaceae), Coutarea hexandra (Jacq.) K. Schum. (Rubiaceae), Esenbeckia febrifuga (A. St.-Hil.) A. Juss. Ex Mart. (Rutaceae), the creeper Smilax sp. (Liliaceae), and the herbaceous Urera baccifera (L.) Gaudich. Ex Wedd. (Urticaceae). The second area, denominated "Deforested area", is located about $300 \mathrm{~m}$ downstream and is composed of herbaceous vegetation where solar radiation strikes the water directly. The land cover is composed of the predominant herbaceous Pycreus decumbens T. Koyama (Cyperaceae),
Hedychium coronarium J. Konig (Zingiberaceae) and Panicum sp. (Gramineae).

Three types of trap were used in both areas to analyse the litter input from all directions: 1) aerial or verticalinput trap, fixed to a metallic frame hanging from nearby trees or stakes (Figure 1a); 2) lateral-input trap, installed on the right and left banks (Figure $1 \mathrm{~b}$ and 1c, respectively), fixed to a metallic frame and held by two stakes; 3) drift or horizontal-input trap, fixed to a metallic frame and with two metal rods used to secure the trap in the bed (Figure 1d). All traps were constructed tying a $1 \mathrm{~mm}$ double plastic mesh to a rectangular metallic frame $\left(0.02 \mathrm{~m}^{2}\right.$; Figure 1e) and eight replicates were used in all cases. We chose to use mesh (as recommended by Elosegi and Pozo, 2005) instead of boxes filled with water (as used by Henry et al, 1994; Uieda and Kikuchi, 1995; Rezende and Mazzoni, 2005; all works analysing only external input) in a way to standardise the sampling devices for external (vertical and lateral) and internal (drift) input analysis, although some loss with leaf fragmentation could probably take place. This type of trap allows rain-

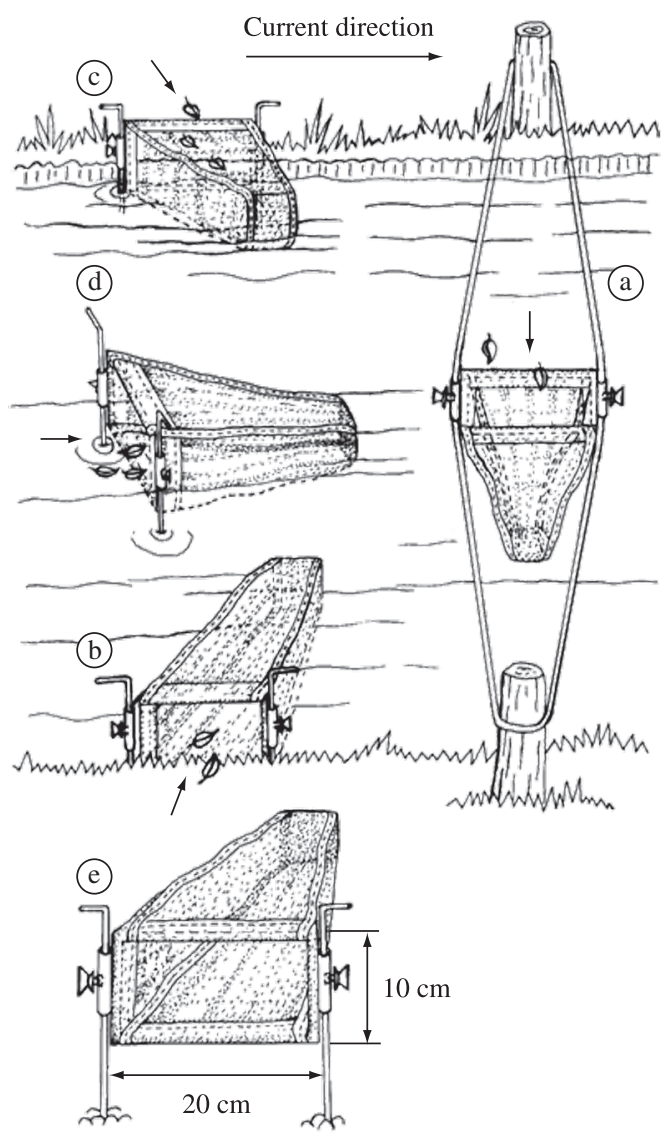

Figure 1. Position of the four traps used to sample: a) aerial vertical-input, b) right and c) left lateral-input, d) drift horizontal-input. The arrows indicate the direction of entry of litter into each trap and e) shows the structure and standard measures of the traps. 
water to drain quickly, but ensures that no material larger than $1 \mathrm{~mm}$ is lost (Elosegi and Pozo, 2005).

The traps were placed in the two areas bimonthly, from May 2004 to June 2005. Each month the traps stayed in the stream for a 48-hour period. After that, the litter captured in the traps was quantified as dry mass separately into three categories: fallen green leaf, fallen dry leaf and coarse particulate organic matter (CPOM, composed mainly of plant fragments not identifiable). The vertical and horizontal input dry mass were expressed in $\mathrm{mg} . \mathrm{m}^{-2} / \mathrm{day}$, considering the trap surface area, and the lateral input dry mass was expressed in $\mathrm{mg} \cdot \mathrm{m}^{-1} / \mathrm{day}$, considering the trap length (Elosegi and Pozo, 2005). The field work was conducted over seven months (May, July, September and November 2004, January, March and June 2005) equally at both areas, although only the months with material sampled were represented in the figures.

During the whole experimental period, some habitat characteristics were measured on the day of litter removal from the traps in such a way to verify if there was a relation with the monthly ratio of litter input. The following variables were analysed: rainfall (obtained from the meteorological station of a farm located about $2 \mathrm{~km}$ from the study location), water temperature, current velocity and discharge (measured as described in Leopoldo and Souza, 1979).

Comparison of dry mass (sum of the three litter fractions) among treatments (areas, months and traps) was done by one-way ANOVA, followed by comparisons with the Tukey HSD test. The relationship between dry mass and environmental parameters was tested using the Spearman Rank Correlation.

\section{Results}

The lateral input of litter differed significantly between areas $\left(\mathrm{F}_{1,110}=19,187, \mathrm{p}<0,001\right.$ for the left bank and $\mathrm{F}_{1,110}=15,594, \mathrm{p}<0.001$ for the right bank), with the higher value of dry mass in the forested area (Table 1). Regarding position of lateral input, no significant difference was observed between right and left banks $\left(\mathrm{F}_{1,110}=0.090, \mathrm{p}=0.76\right.$ in the deforested area and $\mathrm{F}_{1,110}=0.33, \mathrm{p}=0.57$ in the forested area). The months of greatest lateral input of litter were July, September

Table 1. Dry mass (mg. $\mathrm{m}^{-1} /$ day for lateral and $\mathrm{mg} \cdot \mathrm{m}^{-2} /$ day for vertical and horizontal inputs) of litter captured in the traps

\begin{tabular}{ccc}
\hline Traps & $\begin{array}{c}\text { Deforested } \\
\text { area }\end{array}$ & $\begin{array}{c}\text { Forested } \\
\text { area }\end{array}$ \\
\hline Left lateral-input & 89 & 1,006 \\
Right lateral-input & 120 & 1,143 \\
Total lateral-input & 209 & 2,149 \\
\hline Aerial vertical-input & 0 & 3,386 \\
Drift horizontal-input & 69,003 & 84,900 \\
Total aerial and drift-input & 69,003 & 88,286 \\
\hline
\end{tabular}

and November, represented mostly by fallen dry leaves (Figures 2 and 3). Nothing was sampled in May, November 2004 (deforested area) and March 2005 (forested area) in the left lateral trap, and in May and July 2004 (deforested area) in the right lateral trap.

The vertical-input in the stream occurred only in the forested area (Table 1), with a visible annual variation, ranging from 562.5 (March 2004) to 9,576.6 mg. $\mathrm{m}^{-2} /$ day

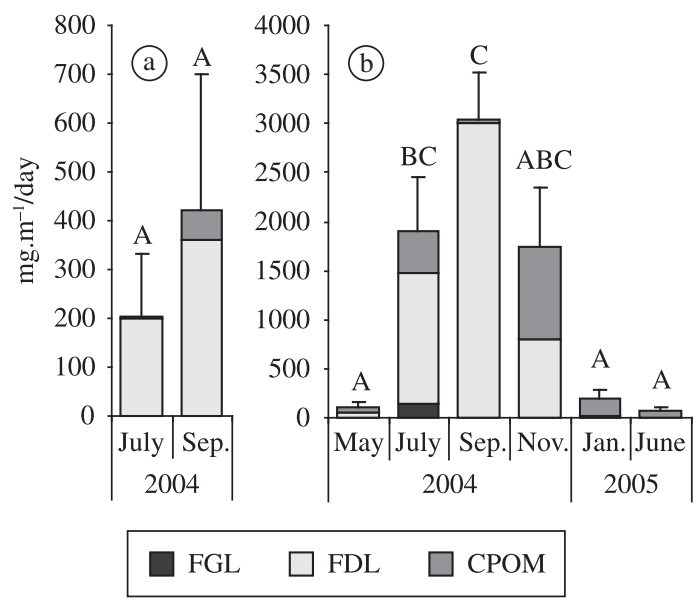

Figure 2. Daily left lateral-input (mean $+\mathrm{SE}$ ) of three litter fractions, in the Deforested a) and Forested areas b) of Ribeirão da Quinta stream. Letters above bars indicate homogeneous groups, obtained by Tukey HSD test. FGL - fallen green leaf, FDL - fallen dry leaf, CPOM - coarse particulate organic matter. The input was analysed at seven months for both areas, but in the figure, only the months with material sampled are represented.

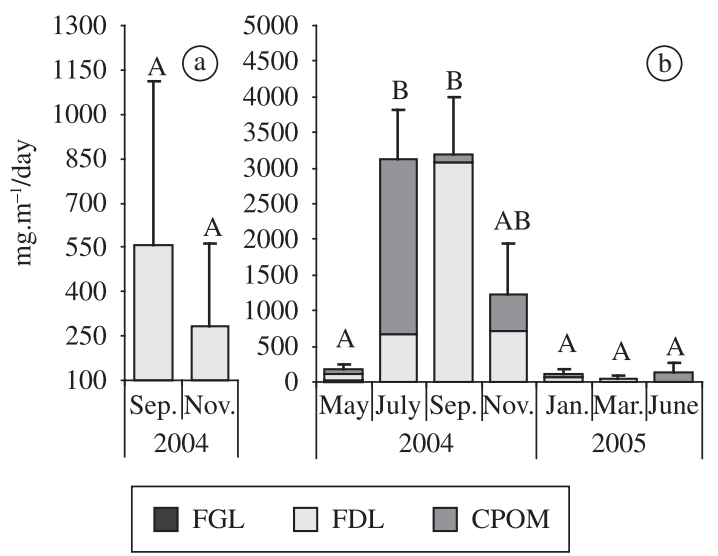

Figure 3. Daily right lateral-input (mean $+\mathrm{SE}$ ) of three litter fractions, in the Deforested a) and Forested areas b) of Ribeirão da Quinta stream. Letters above bars indicate homogeneous groups, obtained by Tukey HSD test. FGL - fallen green leaf, FDL - fallen dry leaf, CPOM - coarse particulate organic matter. The input was analysed at seven months for both areas, but in the figure, only the months with material sampled are represented. 
(September 2004). The aerial input was composed $100 \%$ by leaves, $24.9 \%$ of green and $75.1 \%$ of dry leaves (Figure 4).

The horizontal-input of litter was not significantly different between the two areas $\left(\mathrm{F}_{1,110}=1,658\right.$, $\mathrm{p}=0.20$; Table 1), occurred at all months, and was composed mostly of CPOM (Figure 5). In the defor-

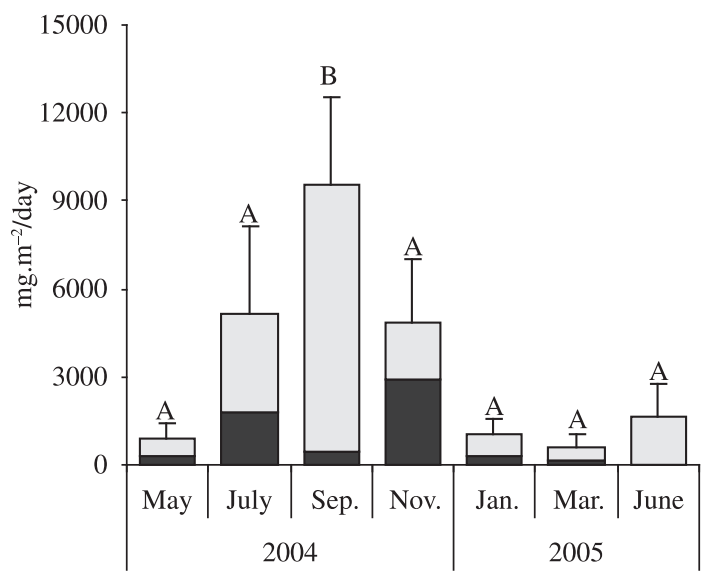

FGL $\square$ FDL $\square$ CPOM

Figure 4. Daily aerial vertical-input (mean $+\mathrm{SE}$ ) of three litter fractions, in the Forested area of Ribeirão da Quinta stream. Letters above bars indicate homogeneous groups, obtained by Tukey HSD test. FGL - fallen green leaf, FDL -fallen dry leaf, CPOM -coarse particulate organic matter. ested area, the month of high horizontal input was June $\left(179,814.5 \mathrm{mg} \cdot \mathrm{m}^{-2} / \mathrm{day}\right)$ and in the forested area it was July $\left(157,395 \mathrm{mg} \cdot \mathrm{m}^{-2} /\right.$ day $)$.

The months of greatest discharge (May 2004 and January 2005) also represented the months of high values of current and rainfall, with the current velocity twice as fast in the deforested area (Figure 6).

The correlation between environmental parameters and drift transport of litter was different between areas (Table 2). Rainfall incidence showed no correlation with litter transport for both areas. However, discharge was positively correlated to drift transport in the deforested area, while current velocity was negatively correlated in the forested area.

\section{Discussion}

In temperate deciduous forests, autumn litter inputs may be as high as $73 \%$ of annual amounts (e.g. Abelho and Graça, 1998). Litterfall in tropical forests may be either seasonal, especially when a marked dry season occurs, or non-synchronous, with litter entering at a relatively constant rate over the entire year (Abelho, 2001; Gonçalves et al., 2006).

Rainfall registered in the Ribeirão da Quinta stream showed two well-defined seasons, with the highest values of litter input during the end of the dry season (September), coincident with the lowest value of discharge. In the same region, Uieda and Kikuchi (1995) and Afonso et al. (2000) found that the litterfall peak occurred in the early wet season (September and October), while Henry et al. (1994) observed it in the late dry season (August). In an Atlantic Rain Forest stream, Rezende

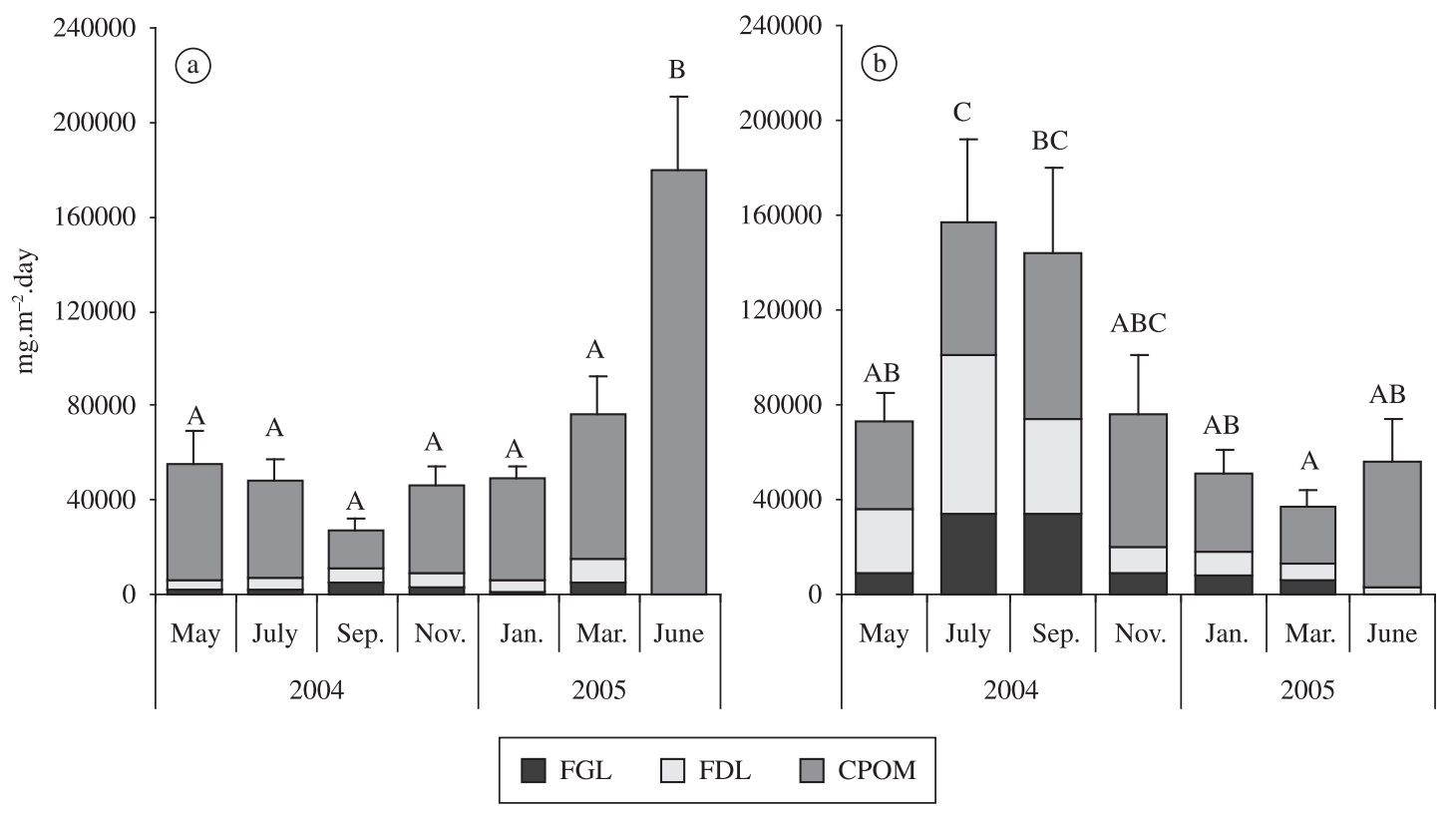

Figure 5. Daily drift horizontal-input (mean + SE) of three litter fractions, in the Deforested a) and Forested areas b) of Ribeirão da Quinta stream. Letters above bars indicate homogeneous groups, obtained by Tukey HSD test. FGL - fallen green leaf, FDL - fallen dry leaf, CPOM - coarse particulate organic matter. 

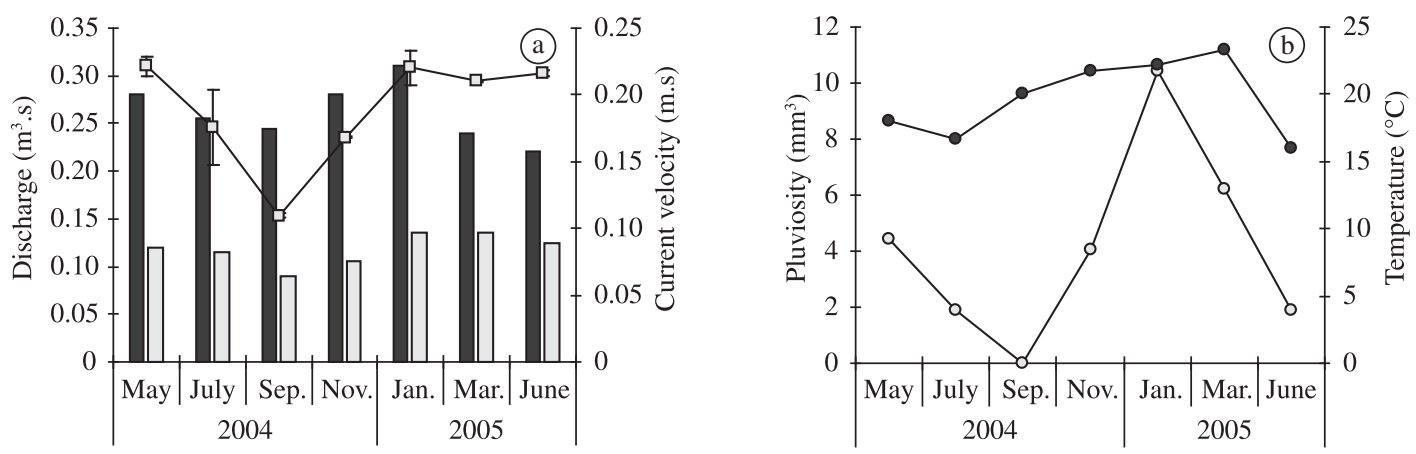

Figure 6. Abiotic parameters of Ribeirão da Quinta determined during the study period: a) water discharge (mean and SD) and current velocity (black bars for Deforested area and white bars for Forested area), b) mean values of rainfall (white; average of the month) and water temperature (black; value of the sampling day).

Table 2. Pearson correlation coefficients of habitat variables and the drift transport of litter in two stretches of the stream (values of correlation significant at $\mathrm{p}<0.05$ ).

\begin{tabular}{lcccccc}
\hline \multicolumn{1}{c}{ Variables } & \multicolumn{2}{c}{$\begin{array}{c}\text { Deforested } \\
\text { area }\end{array}$} & & \multicolumn{2}{c}{$\begin{array}{c}\text { Forested } \\
\text { area }\end{array}$} \\
\cline { 2 - 3 } \cline { 6 - 7 } & $\mathbf{R}$ & $\mathbf{p}$ & & $\mathbf{R}$ & $\mathbf{p}$ \\
\hline Rainfall $\left(\mathrm{mm}^{3}\right)$ & 0.21 & 0.64 & & -0.64 & 0.12 \\
Current velocity $(\mathrm{m} / \mathrm{s})$ & -0.41 & 0.35 & & -0.88 & 0.008 \\
Discharge $\left(\mathrm{m}^{3} / \mathrm{s}\right)$ & 0.79 & 0.036 & & -0.64 & 0.12 \\
\hline
\end{tabular}

and Mazzoni (2005) determined a peak of litter input during the wet season (October, December and February). According to Pozo et al. (1997), the phenology of litter input and discharge regime may be responsible for the temporal litterfall variation.

The significant correlation between water discharge and drift transport of litterfall in the deforested area for pasture utilisation may be related to its location, near the forested area. It is expected that with the increase of water discharge, a great quantity of leaf litter and accumulated benthic organic matter from the gallery forest may be transported downstream. The correlation of litter transport with current velocity in the forested area corroborates the previous argument.

Other authors (Canhoto and Graça, 1998; Afonso and Henry, 2002; Pretty and Dobson, 2004) also found that during rainfall events, leaf retention also decreases greatly. In the same way, when retention structures are submerged or carried downstream, it will result in greater loss of sediments (Díez et al., 2000; Afonso and Henry, 2002). Therefore, when litter input peaks coincide with low flows, CPOM tends to accumulate in the stream bed (Pozo and Elosegi, 2005). On the contrary, if litter inputs coincide with high flows, transport processes are favourable.

The input of litter from the lateral banks was about ten times larger in the forested than in the deforested area, a result similar to that found by Henry et al. (1994) and Afonso et al. (2000), both working in a stream of the same basin. The highest lateral input of litter at the end of the dry season (July) and the beginning of the wet season (September) probably was influenced by two climatic agents: the scouring of this material by the wind during drought and by the rain during flooding. Moreover, the first flood after a long dry period may scour a much larger amount of litter than similar floods later in the season (Elosegi and Pozo, 2005). It is probable that the regional climate associated with the characteristics of semi-deciduous forest could be the main factor that determined this seasonal leaf-litter pattern (e.g. Abelho, 2001).

The transport of litter downstream is a very important parameter for analysis of the energy distribution along the stream, mainly for areas with altered riparian vegetation. In the short stretch of the Ribeirão da Quinta stream studied, one may assume that drift inputs equaled drift outputs, as argued by Elosegi and Pozo (2005). This presupposition is further justified since lateral input occurred rarely and aerial input did not occur in the deforested area, while the drift transport was similar between both areas. The amount of litter transported by drift surpassed the other inputs and the greatest part of the former was made up of CPOM, probably originated from organic benthic stocks. Iversen et al. (1982) also reported a large contribution of CPOM $(92 \%)$ in the output and of leaves in the inputs $(71 \%)$. Clearly, the origin and quality of this organic matter is of great importance to the understanding of stream dynamics.

Also, the composition of the allochthonous matter imported to the stream may influence the community structure and diet of stream fauna (Moulton and Magalhães, 2003; Rezende and Mazzoni, 2005; Uieda and Motta, 2007), and consequently the whole aquatic ecosystem.

The difference in the quality of litter as a function of input origin was very evident. First, a large part of the litter entering a stream channel consists of gallery forest leaves, particularly fallen dry ones. Second, a part of these leaves is directly transported downstream, de- 
posited in the stream channel and on the stream banks. Third, the mobilisation and distribution of stored litter depend on climatic agents, such as rainfall and wind. A large portion of this material imported upstream consists of unidentifiable fragments, originated probably from the breakdown process (e.g. Gessner et al., 1999). Such patterns are very characteristic, as much in tropical (Henry et al., 1994; Afonso et al., 2000; Gonçalves et al., 2006) as in temperate streams (e.g. Graça, 2001).

Given that riparian vegetation is the main source of leaves, and therefore the main energy source (Graça, 2001; Graça and Canhoto, 2006), changes in its composition affect structure and process within streams (Heartsill-Scalley and Aide, 2003). This alteration was clearly shown by the low contribution of leaf litter in the deforested area. In a way to maximise conservation, to establish connectivity and to increase the minimum riparian forest width, priority should be given to the stream ecosystem (Heartsill-Scalley and Aide, 2003).

Acknowledgements - We thank Maria J. Feio, Marcos Callisto, Alaide A. F. Gessner and Claudio G. Froehlich for critical comments on an earlier version of the manuscript. We are grateful to Fabio Vitta and Clemente J. Campos for identification of the plant species. The first author was funded by a scholarship from CNPq.

\section{References}

ABELHO, M. and GRAÇA, MAS., 1998. Litter in a first-order stream of a temperate deciduous forest (Margaraça Forest, central Portugal). Hydrobiologia, vol. 386, p. 147-152.

ABELHO, M., 2001. From litterfall to breakdown in streams: a review. The Scientific World, vol. 1, p. 656-680.

AFONSO, AAO., HENRY, R. and RODELLA, RCSM., 2000. Allochthonous matter input in two different stretches of a headstream (Itatinga, São Paulo, Brazil). Brazilian Archives of Biology and Technology, vol. 43, p. 335-343.

AFONSO, AAO. and HENRY, R., 2002. Retention of particulate organic matter in a tropical headstream. Hydrobiologia, vol. 482, p. $161-166$.

CANHOTO, C. and GRAÇA, MAS., 1998. Leaf retention: a comparative study between two stream categories and leaf types. Verhandlungen der Internationalen Vereinigung fur Theoretische und Angewandte Limnologie, vol. 26, p. 990-993.

DÍEZ, JR., LARRAÑAGA, S., ELOSEGI, A. and POZO, J., 2000. Effect of removal of wood on streambed stability and retention of organic matter. Journal of North American Benthological Society, vol. 1, p. 621-632.

ELOSEGI, A., 2005. Leaf retention. In GRAÇA, MAS., BÄRLOCHER, F. and GESSNER, MO. (Eds.). Methods to study litter decomposition: a practical guide. Netherlands: Springer. p. 13-18

ELOSEGI, A. and POZO, J., 2005. Litter input. In GRAÇA, MAS., BÄRLOCHER, F. and GESSNER, MO. (Eds.). Methods to study litter decomposition: a practical guide. Netherlands: Springer. p. 3-11.

GESSNER, MO., CHAUVET, E. and DOBSON, M., 1999. A perspective on leaf litter breakdown in stream. Oikos, vol. 85, p. 377-384.
GONÇALVES Jr., JF., FRANÇA, JS. and CALLISTO, M., 2006. Dynamics of allochthonous organic matter in a tropical Brazilian headstream. Brazilian Archives of Biology and Technology, vol. 49, no. 6, p. 967-973.

GRAÇA, MAS., 2001. The role of invertebrates on leaf litter decomposition in stream: a review. International Review of Hydrobiology, vol. 86, p. 383-393.

GRAÇA, MAS. and CANHOTO, C., 2006. Leaf litter processing in low order streams. Limnetica, vol. 25, p. 1-10.

HEARTSILL-SCALLEY, T. and AIDE, TM., 2003. Riparian vegetation and stream condition in a tropical agriculturesecundary forest mosaic. Ecological Applications, vol. 13, p. $225-234$.

HENRY, R., UIEDA, VS., AFONSO, AAO. and KIKUCHI, RM., 1994. Input of allochthonous matter and structure of fauna in a Brazilian headstream. Verhandlungen der Internationalen Vereinigung fur Theoretische und Angewandte Limnologie, vol. 25, p. 1866-1870.

IVERSEN, TM., THORUP, J. and SKRIVER, J., 1982. Inputs and transformation of allochthonous particulate organic matter in a headwater stream. Holarctic Ecology, vol. 5, p. 10-19.

LEOPOLDO, PR. and SOUZA, AP., 1979. Hidrometria. Botucatu: UNESP

MOULTON, TP. and MAGALHÃES, SAP., 2003. Responses of leaf processing to impacts in streams in Atlantic rain Forest, Rio de Janeiro, Brazil: a test of the biodiversity-ecosystem functioning relationship? Brazilian Journal of Biology = Revista Brasileira de Biologia, vol. 63, no. 1, p. 87-95.

POZO, J., GONZÁLEZ, E., DÍEZ, JR., MOLINERO, J. and ELÓSEGI, A., 1997. Inputs of particulate organic matter to streams with different riparian vegetation. Journal of North American Benthological Society, vol. 16, p. 602-611.

POZO, J. and ELOSEGI, A., 2005. Coarse benthic organic matter. In GRAÇA, MAS., BÄRLOCHER, F. and GESSNER, MO. (Eds.). Methods to study litter decomposition: a practical guide. Netherlands: Springer. p. 25-31.

PRETTY, JL. and DOBSON, M., 2004. Leaf transport and retention in a high gradient stream. Hydrology and Earth System Sciences, vol. 8, p. 560-566.

REZENDE, CF. and MAZZONI, R., 2005. Seasonal variation in the input of allochthonous matter in an Atlantic Rain Forest stream, Ilha Grande-RJ. Acta Limnologica Brasiliensia, vol. 17, no. 2, p.167-175.

RODRIGUES, RR. and GANDOLFI, S., 2001. Conceitos, tendências e ações para a recuperação de florestas ciliares. In RODRIGUES, RR. and LEITÃO FILHO, HF. (Eds.). Matas Ciliares: conservação e recuperação. São Paulo: Edusp. p. $235-247$

UIEDA, VS. and KIKUCHI, RM., 1995. Entrada de material alóctone (detritos vegetais e invertebrados terrestres) num pequeno curso de água corrente na cuesta de Botucatu, São Paulo. Acta Limnologica Brasiliensia, vol. 7, p. 105-114.

UIEDA, VS. and MOTTA, RL., 2007. Trophic organization and food web structure of southeastern Brazilian streams: a review. Acta Limnologica Brasiliensia, vol. 19, no. 1, p. 15-30.

VANNOTE, RL., MINSHALL, GW., CUMMINS, KW., SEDELL, JR. and CUSHING, CE., 1980. The river continuum concept. Canadian Journal of Fisheries and Aquatic Sciences, vol. 37, p. 130-137. 